\title{
The future of global governance after the pandemic crisis: what challenges will the BRICS face?
}

\section{Francesco Petrone ${ }^{1}$ (D)}

Accepted: 13 April 2021 / Published online: 7 May 2021

(c) The Author(s), under exclusive licence to Springer Nature Limited 2021

\begin{abstract}
In the current international context in which the pandemic has dealt a severe blow, several questions arise in relation to the future of global governance (GG) and the role that emerging countries such as the BRICS (Brazil, Russia, India, China and South Africa) will play in it. First of all, governance itself has been shown to have several deficits and has been radically affected. Furthermore, it is questionable as to what challenges the BRICS will face internally in the future, especially at the end of the pandemic, and whether they will give rise to a new global order. For this reason, in this paper, we analyse the meaning of "power transition" and "hegemony", and we also try to give a reading of some practices carried out by the BRICS in the fields of climate change governance, the inclusion of civil society and the role that these countries play in international institutions such as the United Nations and in forums such as the G20. Having noted the limits in these areas, our idea is that today, more than ever, the need to have a global approach to development is increasingly necessary. Even the BRICS, which in reality do not seem willing to overturn the current international context, will be called upon to play an important role in the future of GG and international relations, specifically in contributing to carrying forward this global development approach.
\end{abstract}

Keywords BRICS · Global governance · Climate change · Civil society · International institutions · Global development

\section{Introduction}

The current global context, which has been so dramatically affected by the COVID19 pandemic, has highlighted several issues related to the international context. First of all, it has made us increasingly aware of the fact that the world is an interconnected place, in which events that occur in one part of it have irreparable

Francesco Petrone

petrone.francesco@gmail.com

1 Department of Philosophy, Universidad de Barcelona, Barcelona, Spain 
repercussions in the rest. In fact, the pandemic, whose first cases were documented in China, immediately afterwards had a tremendous and rapid spread to the rest of the world. Therefore, one of the first points that must be highlighted is precisely that of the close links between states that characterizes the current world order. We could well define this virus as a "problem without passports" (Annan 2009). This famous expression was used by Kofi Annan to indicate those global problems that characterize the whole world, and which therefore have no geographical boundaries. Annan was referring to issues related to climate change, migration, international terrorism and so on. Therefore, he was referring to problems that require global answers.

However, very often it seemed that instead of uniting in a common battle, this moment has often manifested in global fragmentation. On many occasions, there have been criticisms of who had been responsible for spreading the virus (such as Trump's famous expression about the "Chinese virus", many times aimed at denigrating the image of that country), or there have been courses of action that in many cases have led to real diplomatic conflicts on various aspects: for example, the production and distribution of vaccines, or the economic measures to cope with the emergency, such as that undertaken by the European Union, i.e., the Recovery Fund and the European Stability Mechanism (ESM), which have provoked a lot of controversy within the Union.

In such a convulsive context, certainly what is most affected is the very process that should lead to the creation of a more inclusive decision-making mechanism whose aim it would be to produce political decisions that need to be directed toward the common good. In essence, we believe that it has been the very paradigm of global governance (GG) which has been deeply affected. In fact, while in theory GG has tried to be a model of inclusion, in practice it has repeatedly demonstrated its own limitations. And during the era of COVID these limitations have certainly come to the surface even more.

Our idea is that GG represents an adequate analytical tool to describe the structural context of today's world (Weiss 2013). In fact, theoretically speaking it expresses a world in which there is significant interdependence and at the same time a world in which there are different centers of power, and therefore, we could say, a de facto multilateralism. However, in practice GG has been the subject of countless criticisms over the decades, as we will see later.

In this context, the role that the emerging powers are playing within it is important. In fact, these countries, among which the BRICS (Brazil, Russia, India, China and South Africa) seem to be the main representatives, have for some years increased their relevance at a global level. As such, they have claimed their right to express their voice in the international context (BRIC 2009). Their desire to be able to create a governance that reflects a world that has changed and continues to change seems more than legitimate given that: (1) the large size of their populations; (2) the economic growth they have undergone; and (3) the increasingly active role they have played in recent times, especially in the context of certain international institutions and forums such as the United Nations (UN) or the G20 (Stuenkel 2020; Cooper 2014). Among various scholars (Stuenkel 2016), it has also been questioned whether their increased importance at a global level has not also meant a "power transition" 
(Arrighi and Silver 1999; Gilpin 1981), or the birth of a new global "hegemony", in Neo-Gramscian terms (Cox 1983).

In light of current events and of the transformation of this group, within which China certainly plays a greater role, we wonder what challenges this group will have to face after the pandemic in order to continue to build a world that reflects the existing multilateralism (Esteves 2012). In practice, what might their role in future GG be?

\section{Structure and methodology of the paper}

The text is therefore structured in this way. First of all, we will provide a critical reading of the meaning of GG as it has been conceived so far. We will therefore highlight its major limitations and what role the BRICS could play within it. Subsequently, we will analyse the meaning of the terms "power transition" and "hegemony". Upon contextualizing these concepts within the modern, we will try to understand if the BRICS can actually represent a bloc that is capable of enacting this power transition and consequently, implement a new hegemony.

We will then analyse, in the light of our findings, what role the BRICS can have with respect to three issues that will be central to giving rise to a more democratic governance: (1) their attitude toward climate change; (2) the promotion of greater inclusion by increasing the involvement of civil society (CS); and (3) their role within international institutions such as the UN and the international forum represented by the G20, the group which brings together the main economies of the world.

The conclusions will highlight that the BRICS face important limitations in all three areas. Nevertheless, they represent emerging powers that have given rise to a new international context in which as new actors they wish to claim a greater weight. Consequently, even in light of the pandemic which we are experiencing, today more than ever we should start thinking about a world architecture that is based on "global development", that is, on a global approach to the issues that affect us all.

\section{Global governance, its limits and the role of the BRICS}

According to the classic definition given by the 1995 Commission on Global Governance, GG should represent "the sum of many ways individuals and institutions, public and private, manage their common affairs. It is a continuing process through which conflicting or diverse interests may be accommodated and co-operative action taken. It includes formal institutions and regimes empowered to enforce compliance, as well as informal arrangements that people and institutions either have agreed to or perceive to be in their interest" (Commission on Global Governance 1995, p. 70).

Therefore, this definition puts the emphasis above all on the many initiatives that should lead to accommodating divergent interests, especially in a world that is constantly changing. 
Despite this vision, that we could define as encouraging, there have been several criticisms of this paradigm. We have already referred to these criticisms (Petrone 2019a, b) and how they especially highlight the fact that, behind the apparent demand for greater inclusiveness, in reality GG hides a series of problems that undermine its very nature. For example, at a linguistic level there are limitations due to the inherent ambiguities in its very meaning when translated to other languages i.e., its "difficult translatability into languages other than English" (Friedrichs 2005, p. 52). ${ }^{1}$ Hence, the origin of the term itself is not neutral origin and is strongly linked to English/American linguistic dominance in the field of International Relations.

At the same time, other issues can be linked to the way in which this "co-operative action" was put into practice. In fact, at a global level GG has been repeatedly criticized precisely because, while in theory it wanted to represent this increased cooperation, in practice it instead expressed old forms of hegemony which were then reflected in a whole series of international institutions. For example, by means of international institutions such as the International Monetary Fund (IMF) and the World Bank (WB), Western countries, with the USA at the lead, have actually projected their advantage economic condition upon the world, thereby extending their moods and their will to the rest of the world (Stiglitz 2002). Through these international institutions, Western countries have put into practice, especially in the second half of the last century, those practices that go by the name of "good governance" (Hermet 2008), which were actually aimed at expanding their neoliberal system globally. Thus, we could say that in this way they exercised a form of hegemony over the rest of the world. In practice, through the indications that the developing countries had to follow, and therefore the good practices that they had to implement, the Western countries did nothing but extend their control over these areas of the world.

There were also scholars like Weiss (2013) who, while acknowledging the limitations of governance, described the gaps that should be overcome to make it effective. Its aim is to find a solution to these gaps in order to give rise to a governance that works. ${ }^{2}$ However, although it seems to us that the time needed in order to overcome these gaps would be lengthy, in any case, the current world order seems to definitely undermine the version of governance as it has been understood up to now.

In summary, there are a series of criticisms that undermine the credibility of the governance paradigm. However, the aspect that seems indisputable is

\footnotetext{
1 On this point, Friedrichs states: "It is hard to translate "governance" into languages other than English, where the Oxford English Dictionary traces the term back by the well into the fourteenth century. Thus, the French "gouvernance" is easily discernible as a loan translation. Whereas "governação" and "governança" have conquered a firm place in the Portuguese vocabulary, "gobernanza" still sounds odd to Spanish ears. The Italians have simply assimilated the English term into their domestic vocabularies, and the same is true for the Germanic and probably also for the Slavic languages. Given its difficult translatability into languages other than English, it is reasonable to assume that the term "global governance" is culturally not neutral. [...] It is relatively clear that the conceptual diffusion of global governance into other language areas would be unthinkable if America was not the center, and if English was not the lingua franca of the international relations discipline".

${ }^{2}$ For Weiss, there are five fundamental gaps in GG practice: Knowledge Gaps, Normative Gaps, Policy Gaps, Institutional Gaps and Compliance Gaps.
} 
precisely that which is linked to this new form of hegemony that Western countries exercised over the rest of the world. Not to mention the policies implemented through the IMF, heavily criticized among others by Stigliz (2002), which were aimed precisely at extending the productive, economic and social model to the rest of the world.

In short, faced with severe limitations presented by the traditional functioning of governance, the emergence of the BRICS countries has undoubtedly represented an upheaval to this situation, if not a major challenge (Petrone 2019a, b).

The BRICS have repeatedly criticized this international system, claiming their right to be able to participate more decisively in global decisions, given that their increased weight and importance on a global level has become considerably greater.

\section{A power transition and a new hegemony?}

In recent years, the weight of the BRICS has increased in the international context. Driven by the desire to make their increased presence felt globally, these countries have joined forces to try to create a compact bloc capable of reshaping the international system. In their view, the current world should not only reflect more precisely this new reality, and therefore, their increased weight. It must also reflect the needs of countries that have been excluded from decision-making processes, and that have suffered under debt policies over the years: these being the countries of the Global South.

At the same time, the BRICS have initiated a whole series of initiatives which in some ways have made us ponder their desire to give rise to a new world order: in addition to the aforementioned increased cooperation, other important initiatives include the establishment of their own bank, called the New Development Bank (NDB), which in practice would operate in "parallel" to the traditional Bretton Woods institutions, and specifically the IMF (Esteves et al. 2016; Abdenur and Folly 2015).

Together with a whole other series of initiatives, such as that of having increased their presence in Africa and other parts of the Global South (Petrone 2020), or their growing interest in acquiring greater accountability through massive investments in "soft power" (Chatin and Gallarotti 2016) -to cite just a few examples-these countries have suggested that they do indeed wish to create a new world order. Given also the fact that the West appears increasingly in decline (Stuenkel 2020, 2016; Acharya 2014), perhaps their impressive growth could probably give rise to a profound transformation of the international system. There are therefore two important questions emerging from the growing presence of the BRICS globally, and their increased power: firstly, whether their breaking into the international system is a moment of "power transition" and secondly, if at the same time this transition of power will lead to a new global "hegemony".

We will examine both concepts to understand whether in the case of the BRICS we can indeed speak of power transition and new hegemony. 


\section{Power transition}

According to classical theories, the term "power transition" describes a process that has a cyclical nature. It describes the rise of new emerging powers, in correspondence to the decline of other powers that have dominated the international scenario so far (Gilpin 1981; Arrighi and Silver 1999). For some authors, this constant on a global level represents a moment of tragedy, since this continuous and cyclical alternation of hegemonic powers makes the international system unstable (Ikenberry and Wright 2008). Furthermore, what the scholars highlight is that there are constantly rising powers on a global level, the "emerging powers": i.e., countries that have increased their economic weight globally. Therefore, this natural process of change is something that always happens, and the cause is the rise of the emerging powers that fight to be recognized. They struggle to acquire a role that belongs to them because of their growth power, and claim greater protagonism on the international chessboard. Is the same thing happening with the BRICS now? Are these countries a challenge to the old global order and are they imposing themselves as hegemonic powers, or new hegemonic powers?

If we consider the data related to their economic growth and their demography, ${ }^{3}$ these show that currently the combined weight of these countries is significant in the global framework. Moreover, these countries have often attempted to find common ground on which to open collaborations on a global level, to exercise decisive pressure. However, it seems that taken individually, these countries are not able to act as hegemonic powers (except perhaps in the case of China). Taken individually, they appear stronger as regional powers where they are able to effect greater regional influence (Buzan and Waever 2003). At a global level however, they seem to be more effective when they work within the BRICS framework.

According to Gilpin (1981), power transition takes place at very specific moments and in certain well-defined circumstances. First, it occurs when new emerging powers do not feel they are adequately represented at the global level. In this case, as history teaches (Kennedy 1987), several strong powers dominated the global scene and then, after their decline, gave way to other "new" powers. For Gilpin, this situation can occur both with the use of force or in a peaceful way (as in the case of England between the end of the nineteenth and the first half of the twentieth century). The ability of these powers to create this transition also depends largely on how they use their available resources and on the type of alliances they manage to establish.

In the case of the BRICS, their alliance has been cemented above all by the fact that these countries have common interests, and more precisely, ever since the

\footnotetext{
3 "BRICS brings together five major emerging economies, having 23 per cent of the global GDP and around 17 per cent of the share in world trade (they have a combined nominal GDP of USD 16.6 trillion). The five nations account for 50 per cent of the world economic growth, 42.58 per cent of the world population (over 3.6 billion people), 26.6 of the world land area and 13.24 per cent of World Bank voting power". Source: "Brics: All you need to know about the 11th summit in Brazil", in Times of India, November 13, 2019. Available from:

https://timesofindia.indiatimes.com/india/brics-all-you-need-to-know-about-the-11th-summit-in-brazil/ articleshow/72032991.cms). [Accessed: 07/01/2021].
} 
moment in which they began to achieve greater weight at an international level. In particular, they have managed to increase their standing within those global institutions where previously their new power was not been reflected. In their opinion, these institutions (and, broadly speaking, the whole world order) needed to be changed because they did not mirror the fact that new actors had entered the global stage and demanded to have a greater voice within them. Their "union" was therefore born initially for this reason: in order to unite their common interests in a changing global order and gain greater representation.

\section{Hegemony}

The term "hegemony" has been used extensively in the Marxist tradition. Following on from the meaning in which Marx himself understood it, this concept was later to be further developed by Antonio Gramsci in a unique way. Gramsci's vision was to have a strong influence in the theory of international relations, especially in the NeoGramscian school. Therefore, it is worth giving a brief introduction to this concept.

First of all, according to Marx, what underlies world politics, which is the reflection of various national politics, is the concept of class struggle (Özçelik 2005). At the same time, at a global level, there are development imbalances in the sense that development tends to favor industrialized countries at the expense of others. Thus, as Lenin would later state (1916), from this situation, the aggressive policy that European countries would go on to implement at the end of the nineteenth century in the form of Imperialism would arise. In fact, Lenin, who noted the contradictions inherent to the capitalist system as described by Marx, points out precisely how Imperialism is "the highest stage of capitalism" (Lenin 1916), that is, a direct consequence of the uneven development which occurs at a world level. In light of these statements, it can therefore be understood that for Marxists the term hegemony is in reality mainly used as a synonym of "dominance". We speak of the domination of the bourgeoisie over the proletariat, but also of domination by more industrialized countries over the countries of the so-called third world.

The one who was to give a unique interpretation of the concept of hegemony was Antonio Gramsci. And his interpretation also went on to have great success in the subsequent debate on international relations.

For Gramsci, the term "hegemony" should be understood as an intellectual and spiritual reform that radically transforms the habits and customs of a given society (Fonseca 2016; Gramsci 1971). It is therefore a sort of ability to define new cultural contents within which, with new cultural production, that economic relations must be conceived and the actions of the political actors who act within it must be interpreted. In Gramsci's view, the subject called upon to influence the sphere of civil society (CS) was the factory proletariat, in line with the Marxist tradition. This historical subject is called upon to influence CS because this is the sphere in which the meaning of cultural values must be changed in terms of cultural hegemony. The proletariat must create a "historical bloc", that is, a set of social forces (including the peasants), which gravitate toward the proletarian political area, and at the same time toward a group of "organic intellectuals", 
that is, a group of intellectuals who place themselves within the working class by supporting its hegemonic struggles. In practice, it is within this sphere that the working class supported by the organic intellectuals should act in order to eliminate the hegemony of the dominant groups and establish their own hegemony to be exercised over the rest of society. It is therefore evident that ideologies play an important role in the scheme developed by Gramsci given that they become autonomous instruments of intellectual and cultural influence. They thus become "hegemonic", and within this hegemony the organic intellectuals play an important and central role since they are the intellectuals who choose to place themselves alongside a social class and its political expression in order to achieve hegemony over the whole of society.

One of the major heirs of Gramscian theory was undoubtedly Cox. For him, however, the term hegemony has a very similar meaning to that of dominance. In fact, for Cox, hegemony is a "structure of values and understandings about the nature of order that infuse a whole system of states and non-state entities" (Cox 1992, p. 140). These values and understandings represent a stable organization that is underpinned by a structure of power. However, in this power structure, the fact that a state is dominant does not automatically determine its hegemony. In fact, according to Cox, "hegemony derives from the ways of doing and thinking of the dominant strata of the dominant state or states insofar as these ways of doing and thinking have acquired the acquiescence of the dominant social strata of other states" (Cox 1992, p. 140; Özçelik 2005, p. 99).

As a consequence of this vision, it therefore happens that for Cox, it is the ruling class of a particular nation that establishes its hegemony over the rest of the world. In practice, hegemony is an expansion beyond the national borders of the national hegemony established by the dominant class. In this context a "dominant mode of production, culture and system of social institutions penetrates all countries" (Cox 1992, p. 137). Thus, world hegemony is a "social structure, an economic structure and a political structure; and it cannot simply be one of these things but must be all three" (Cox 1993, p. 62). In Cox's view, a necessary transformation of global structures takes place, especially in the terms of "the dynamics and dialectics of their normative [ethical, ideological, practical] as well as their material dimensions" (Stephen and Law 1993, p. 94).

The historical block also plays an important role across national borders for Cox. In fact, this historical block is organized around the dominant ideology which is the basis of a union between social forces (political and civil society) and which exercise an "intellectual and moral leadership". (Cox and Sinclair 1996). By extension, this historical block is extended internationally: "a hegemonic order therefore emerges out of the successful formation of an international historic bloc of social forces [...]. The hegemonic world order (intellectual and moral leadership in international system) is created by the interactions between the dominant state and dominant social forces and the subordinate states and social forces. In other words, it is a product of a universal dominant society and civilization" (Cox 1992, p. 141).

Thus, in our opinion, the concepts of power transition and hegemony are closely linked to each other. And it is probably from the intersection of these two practices that we must ask ourselves what direction future GG will take. In practice, then, the 
question to ask is whether the BRICS can actually be the vectors of this transition toward a new hegemony.

\section{The limits of the BRICS in climate change, in greater democratic participation, and in international institutions}

On the basis of what we have seen thus far, some questions arise as to whether the BRICS are actually capable of exercising a new hegemony or if instead, as a block they are giving rise to a transition of power. Even if these are important questions to answer, in our opinion, there are two issues which actually highlight key limitations with respect to these points. Firstly, it seems that their interest is not (for now) directed to completely upsetting the current global order, and therefore to the creation of a "parallel" one. And secondly, there are unresolved questions regarding how they plan to deal with the challenges posed by the current world order and what their true vision is of how future GG should look like.

We will discuss these two points in the following paragraphs.

Regarding the first point, we can take the creation of parallel bodies such as the aforementioned NDB and also the CRA (Contingent Reserve Arrangement) as an example. These institutions reflect a new financial order which contrasts with that led by the West and which is represented by the IMF and/or the WB. Contrary to these institutions, it seems that they are pursuing goals that would make us believe that their true objective is not to give rise to a parallel order. Even if they had been created to speed up the promotion of projects for cooperation and investment in infrastructures, in reality, the very fact that they are inspired by principles of nonintervention in the sovereignty of other states certainly offers an opposing vision when compared to the role of the traditional Bretton Woods institutions (Matthew and Parízek 2017). The latter, in fact, by promoting "good governance" also required specific structural reforms within each state that requested loans. Thereby, effectively widening the sphere of influence of those liberal policies promoted within Western countries. In this way, they have affected the sovereignty of other states, especially those in the Southern hemisphere. Thus, Western countries have given the impression of wishing to condition the political choices of Southern countries, and at the same time, creating a dependence (due to the debts contracted) that bound them even further to international institutions such as the IMF.

On the other hand, taking these facts into consideration, the BRICS have instead claimed the need to recognize their increased power and influence, and therefore of their right to make their voices heard on the international scene. In practice, according to their vision, it is necessary to maintain the current order but at the same time, to increase the democratization of governance and decision-making processes as they have been thus far conceived. Therefore, their request seems to be directed more toward greater participation within an already established international context, rather than completely upsetting the existing order.

However, while on the one hand their demands seem to be directed toward reshaping the existing world order from within, on the other hand, it is not yet clear what their contribution will be to the international system that they wish to create. 
In fact, several questions arise in many areas. We could list many, but in this paper we limit our enquiry to asking a few questions concerning key areas that may contribute to building a GG with a "human face" (Falk 1995). If the current international system and the GG paradigm is in crisis, and the BRICS demand its reform, what vision do they have of its future? In particular, what is their real commitment to areas such as climate change, the role of civil society (CS) and their engagement in international institutions and/or in international forums such as the UN or the G20?

We have selected these areas because, in our opinion, these three points represent some of the key sectors from which it may be possible to truly reshaped GG for the future.

With respect to the first point on climate change, there is a real contradiction between what the BRICS promise in theory and what they have put into practice. In fact, based on what we have already investigated in other works (Petrone 2019a, b), we have seen that the BRICS have claimed on multiple occasions that they wish to become leaders and promoters of a global order that deals first and foremost with global issues such as climate change (Xinhua 2017). However, if we take into account their results in terms of adaptation and mitigation, we must admit that their results remain discouraging, especially with regard to the 2015 Paris agreements (COP21).

In fact, China, India and South Africa are still largely dependent on coal, which represents half of the total energy demand in all three countries, and both in Russia and Brazil oil and gas represent the main source for the primary energy demand: 73\% in Russia and 62\% in Brazil (Downie and Williams 2018). At the same time, there are no encouraging answers when taking into consideration their shift toward alternative energies and the reduction of their emissions. In fact, four of the five members achievements are classified as "insufficient" (Brazil), "highly insufficient" (China and South Africa) and "critically insufficient" (Russia) on Climate Action Tracker (2021) web page. Only India is rated " $2{ }^{\circ} \mathrm{C}$ compatible". After adopting its National Electricity Plan (NEP) in 2018, India's climate action was considered to be on track to achieving the Paris COP21 Agreement (Climate Action Tracker 2021). This means that for the BRICS, there is still a long way to go in order to fulfill their COP21 commitments, and above all to reach common targets.

Thus, their dependence on obsolete forms of energy represents a significant limitation on their promises. Therefore, it should be asked whether in the future they will really be able to turn themselves into promoters and leaders in this area. Moreover, it is worth asking if they genuinely wish to start a real process of energy transition as hoped for in the COP 21 in Paris, the famous historical event that should have marked a watershed with regard to climate change policies, but which in fact still proved to be wanting. ${ }^{4}$ Thus, in the context of climate change governance, if in

\footnotetext{
4 In reality, the gaps do not concern only the BRICS countries, but also and above all Western countries, whose treatment of the policies related to climate change has so far been contradictory. Indeed, on the one hand, the US with Trump had withdrawn from the Paris agreements. Thus, the newly elected President Biden will have to make up for this gap, not an easy task. On the other hand, in Europe, which has unfortunately been the victim of strong fragmentation and populism in recent years, as well as of a major economic crisis, real commitment toward the climate has often appeared vague.
} 
the future the BRICS really want to make a contribution, they should then actually commit to putting into practice clear and specific policies toward an energy transition. Otherwise, their statements will remain at odds with what they put into practice and consequently, it would seem that they were mainly aimed at increasing their soft power rather than at having real and concrete effects (Petrone 2019a, b).

As regards the role of CS in decision-making processes, it seems to us that CS must also have an important role in the BRICS countries. If they really want to be the promoters of a world in which there is a real democratization process, CS involvement is key. In fact, "civil society activities are an enactment of citizenship, that is, they are practices through which people claim rights and fulfill obligations as members of a given polity." (Scholte 2011, p. 34).

According to the definition that the Commission on Global Governance gave in 1995, by CS we mean "a multitude of institutions, voluntary associations, and networks-women's groups, trade unions, chambers of commerce, farming or housing co-operatives, neighborhood watch associations, religion-based organizations and so on. Such groups channel the interests and energies of many communities outside government, from business and the professions to individuals working for the welfare of children or a healthier planet [...] citizens' movements and NGOs now make important contributions in many fields, both nationally and internationally. They can offer knowledge, skills, enthusiasm, a non-bureaucratic approach and grassroots perspectives, attributes that complement the resources of official agencies" (Commission on Global Governance 1995, pp. 32-33).

In short, CS represents a fundamental area for creating accountable governance. In particular, in the countries of the Global South, the role of CS is important in bringing those social questions that concern the most marginalized parts of the population to the center of the agenda of their respective countries. At the same time, a strengthening of the role of CS in the countries of the global South, and of the BRICS in particular should also result in a greater capacity to propose a vision of governance that does not depend on the civil societies (CSs) of the North of the world. In fact, according to Scholte (2011, p. 57), "Southern stakeholders do not wish to be considered a constituency of Northern NGOs, and want direct voice for themselves".

Our idea is therefore that CS should play an important role in GG. And regarding CS, BRICS statements on the matter seem oriented toward building a system that can take into account the contribution of all those associations that should have an important role in decision-making.

However, even in this case, although in theory they declare the importance of CS in decision-making processes, in practice it seems that the role of CS is not yet all that decisive in the BRICS countries. In fact, in this area there have been criticisms of the modus operandi of the BRICS governments (BRICS Policy Center 2016) and at the same time, in our opinion, CS itself suffers from its own limitations. Among these limitations, a solid network between the CSs of the different BRICS countries is certainly missing (Poskitt et al. 2016), this in spite of the efforts made to kick start initiatives aimed at promoting participation in decision-making contexts.

In the future, this role will also have to be taken into consideration so as to be able to offer a response to the role of CS. According to what we have already stated, 
CS should bring the needs of those actors who are traditionally excluded from decision-making processes to the center of the discussion.

Finally, we consider the role of these countries in the context of international institutions such as the United Nations (UN) or the G20.

Regarding the UN, it seems to us that with respect to their role in the Security Council (SC) of the United Nations, the true supervisory body, there are contradictions. First of all, we have to remember that two of the SC permanent five members are BRICS countries, namely Russia and China. At the same time, we should also note that over the years countless proposals for reform of the United Nations system have been made (without any effect) (Abb and Jetschke 2019). Once again another interesting aspect of the BRICS modus operandi appears here. While on the one hand China and Russia support the demands of India and Brazil for a reform of the CS system, on the other hand, they have done nothing to bring about this reform (Petrone 2021; Abb and Jetschke 2019). More than likely, their privileged role within this institution has prevailed over their real interest in giving access to the SC to these other countries.

As for the G20, even within this group the BRICS have very often given the impression of having rather contradictory objectives. Indeed, on the one hand, it seems that their aim has frequently been to seek greater transparency in decisionmaking processes, and therefore, also to make the G20 a means of creating a more inclusive GG. However, on the other, very often their line of action has also turned to the purpose of achieving higher standards of recognition within the group of the most economically powerful countries on earth (Cooper 2014).

In short, even in this case, it seems that if on the one hand their statements express a greater desire for international inclusiveness, a greater democratization of decision-making processes and in general a reshaping of GG, in practice, their way of acting has very often shown significant limitations which can be linked precisely to their national interests, and therefore to a lack of cohesion among them. In the future, the challenges that these countries will be called upon to carry out will be to try to find a common position and pursue it, both in theory and in practice.

These examples, climate change, the role of CS and the behavior of the BRICS within international institutions show us (although, as mentioned, other areas could also be considered) that the BRICS still have a long way to go and therefore, that there are issues that they will have to address where they will have to increase their cooperation.

At the same time, we wish to point out that, although these countries will surely find greater homogeneity, they will still have lots a multitude of problems that they will not be able to deal with by remaining isolated (nor also as a block). This means that in order to make the world order work, they should try to promote a global approach toward "global development", especially with regards to the global issues that concern us most closely nowadays.

What has been discussed so far not only highlights that we are not, at least for now, facing a transition of power or a new global hegemony, but also that there are numerous gaps to be filled by the BRICS in order to be a truly accountable and compact group. At the same time, it is important to highlight another point that could emerge from these analyses: the fact that rather than demanding different spheres of 
power, and therefore increasing the divisions between different blocs in the current world, nowadays, we should instead start thinking about a truly global approach to global problems. The pandemic has done nothing but reconfirm this pressing need.

\section{Conclusions: a global approach is needed}

The situation that has arisen in the past year highlights something which is even more important: rather than talking about new hegemonies or transitions of power, it would be more correct to undertake a discourse that has a global approach to global problems.

Nowadays, there is a new direction emerging from the literature concerning global politics and international relations on the need for a global response to global problems. Recent global issues also testify to the need for a new direction. In this sense, one particular paradigm seems to represent the most appropriate theoretical framework in which to describe the current global situation and the importance of collective action in order to tackle those issues of global interest. This paradigm is the "global development" approach (Oldekop et al. 2020; Horner and Hulme 2017).

There are several practices, already in place, which seem to indicate this approach is being put into practice. For example, the Sustainable Development Goals (SDGs). Ever since the SDG implementation in 2015, its goals have seemed oriented in particular toward a global approach to global issues. Even if in recent years a certain degree of populism has arisen, supported by neomercantilist purposes of a state centric role in international relations, the direction initiated in this field by the SDGs is important to understand that our "common neighborhood" (Commission on Global Governance 1995) has to be considered as a whole.

Global development, in this sense, means an overarching focus that considers development in relation to the whole world. We live in a world where many of the causes of development cannot be segmented along North-South lines or national boundaries. Thus, the future of GG stands in its ability to advocate for a "one-world" approach and in its capability to promote the need for "greater mutual learning, and associated collaborative action, across and within the Global North and South" (Horner 2019, p. 429).

In this context, the BRICS should promote a multilateral global order, as they currently claim, however one which really aims to have a global development approach. In our opinion, in this case they could genuinely act as real models to follow, and therefore improve their image.

While the world is going through a dramatic moment in its history due to the current pandemic, new perspectives may open up for consideration in the near future. In fact, what we are currently experiencing is a moment of upheaval in which several issues are arising. For instance, there are certain problems emerging from the administration of the welfare state. Public hospitals and social work will have tremendous repercussions from the current state of affairs.

However, there are some issues that may be taken in consideration which may represent a true turning point. One of the most important lessons from the current situation is that the virus has no national borders. Thus, current issues affect the 
world as a whole. In this situation, it is not correct or fair to consider the situation as only belonging to an individual state. The problem can surely be considered as a problem that belongs to the above-mentioned Kofi Annan's "problems without passport": the spread of the virus worldwide has to be considered as something that affects all us. But at the same time, it is a moment in which a holistic approach to global problems could be considered not only for the virus but also for the most important issues that we are facing nowadays. In brief, the COVID pandemic shows that we will need a global development approach to our problems, and that among those there are some that require immediate action (such as climate change, again another challenge of great magnitude among the many problems of present times).

We are in the presence of a series of processes which the historian Fernand Braudel (1949) would have called the "longue durée", i.e., long term, of historical phenomena (Lee 2012). In other words, these are events which are neither ephemeral nor casual and which force global society to rethink itself, its own cultural tradition, its own anthropological status and its own future which will in any case be increasingly interconnected.

In order to face future challenges, countries like the BRICS are also called upon to make their contribution. In this paper, we have analyzed how they do not intend to create a new world order or a transition of power. Rather, they would like GG to be more inclusive, reflecting the multilateralism that indeed already exists.

However, regarding their contribution to GG, there are several limitations that still characterize these countries. We have extended our analysis only to the three areas of climate, CS and the role these countries play in international forums. The result has been that, at first glance, in those areas which are important for the future of GG, these countries still suffer from many limitations and contradictions. However, these limits and contradictions will have to be overcome in the future not in order to create a new hegemony or a transition of power. Rather, it seems to us that among the objectives that the BRICS, in concert with the other countries, should include the promotion of goals in pursuing global development. That is to say, the creation of a "single world" (Bangura 2019, p. 12) in which a global approach is used to solve "problems without passports", thereby replacing individualism, fragmentation and national interests.

\section{References}

Abb, P., and A. Jetschke. 2019. The devil is in the detail: The positions of the BRICS countries towards UN security council reform and the responsibility to protect. In Contested world orders, rising powers, non-governmental organizations, and the politics of authority beyond the nation-state, ed. S.D. Matthew and M. Zürn, 167-201. Oxford: Oxford University Press.

Abdenur, A.E., and M. Folly. 2015. The new development bank and the Institutionalization of the BRICS. Revolutions Global Trends \& Regional Issues 3 (1): 66-92.

Acharya, A. 2014. The end of American world order. Cambridge: Polity Press.

Annan, K. 2009. Problems without Passports. Foreign Policy, 11 September, http://foreignpolicy.com/ 2009/11/09/problems-without-passports/. Accessed 15 January 2021.

Arrighi, G., and B.J. Silver. 1999. Chaos and governance in the modern world system. Minnesota: University Press.

Bangura, Y. 2019. Convergence does not equal equality. Development and Change 50 (2): 394-409. 
Braudel, F. 1949. La Méditerranée et le monde méditerranéen à l'époque de Philippe II. Paris: Librairie Armand Colin.

BRIC. 2009. 1st BRIC Summit Yekaterinburg Declaration. 1st BRICS Summit, 16 June. http://en.kreml in.ru/supplement/209. Accessed 20 January 2021.

BRICS Policy Center. 2016. Radar Socioambiental. Rio de Janeiro, n. 7, October. http://bricspolicycent er.org/homolog/publicacoes/interna/7186?tipo=Radar. Accessed 01 October 2020.

Buzan, B., and O. Waever. 2003. Regions and powers: the structure of international security. Cambridge: University Press.

Chatin, M., and G.M. Gallarotti. 2016. The BRICS and soft power: an introduction. Journal of Political Power 9 (3): 335-352.

Climate Action Tracker. 2021. Available at: https://climateactiontracker.org/. Accessed 15 January 2021.

Commission on Global Governance. 1995. Our global neighborhood. Oxford: Oxford University Press.

Cooper, A.F. 2014. The G20 and contested global governance: BRICS, middle powers and small states. Caribbean Journal of International Relations \& Diplomacy 2 (3): 87-109.

Cox, R.W., and T.J. Sinclair. 1996. Approaches to world order. Cambridge: Cambridge University Press.

Cox, R.W. 1993. Gramsci, hegemony and international relations: an essay in method. In Gramsci, historical materialism, and international relations, ed. S. Gill, 49-67. Cambridge: Cambridge University Press.

Cox, R.W. 1992. Towards a post-hegemonic conceptualization of world order: reflections on the relevancy of Ibn Khaldun. In Governance without government: order and change in world politics, ed. J.N. Rosenau and E.O. Czempiel, 132-160. Cambridge: Cambridge University Press.

Cox, R.W. 1983. Gramsci, Hegemony and International Relations: An Essay in Method. Millennium: Journal of International Studies 12 (2): 162-175.

Downie, C., and M. Williams. 2018. After the paris agreement: what role for the BRICS in global climate governance? Global Policy 9 (3): 398-407.

Esteves, P., G. Torres, and G.G. Zoccal. 2016. Os BRICS e o Novo banco de desenvolvimento. BPC Policy Brief, Rio de Janeiro 6(3). http://www.bricspolicycenter.org/publicacoes/os-brics-e-onovobanco-de-desenvolvimento/\#contact_popup. Accessed 16 January 2021.

Esteves, P. 2012. Brasil, los BRICS y la agenda multilateral en el siglo XXI. In América latina y el caribe: vínculos globales en un contexto multilateral complejo, ed. F. Rojas Aravena, 151-178. Buenos Aires: Editorial Teseo.

Falk, R. 1995. On human governance. toward a new global politics. Cambridge: Polity Press.

Fonseca, M. 2016. Gramsci's critique of civil society: towards a new concept of hegemony. Routledge studies in social and political thought book. London: Routledge.

Friedrichs, J. 2005. Global governance as the hegemonic project of transatlantic civil society. In Criticizing global governance, ed. M. Lederer and P. Muller, 52. Basingstone and New York: Palgrave Macmillan.

Gilpin, R. 1981. War and change in world politics. Cambridge: University Press.

Gramsci, A. 1971. Selections from the prison notebooks of Antonio Gramsci. New York: International Publishers.

Hermet, G. 2008. Populismo, democracia y buena gobernanza. Barcelona: El Viejo Topo.

Horner, R. 2019. Towards a new paradigm of global development? Beyond the limits of international development. Progress in Human Geography 44 (3): 415-436.

Horner, R., and D. Hulme. 2017. From International to Global Development: new Geographies of 21st Century Development. Development and Change 50 (2): 347-378.

Ikenberry, J.G., and T. Wright. 2008. Rising powers and global institutions. A century foundation report. New York: The Century Foundation.

Kennedy, P.M. 1987. the rise and fall of the great powers: economic change and military conflict from 1500 to 2000. New York: Random House.

Lee, R. 2012. Fernand Braudel, the Longue Duree, and world systems analysis. Albany: State University of New York Press.

Lenin, V. I. 1916. Imperialism: the highest stage of capitalism. Written: January-June, 1916. Source: selected works, vol. 1, 667-766. First Published: Early 1917. Online Version: Lenin Internet Archive (marxists.org).

Matthew, S., and M. Parízek. 2017. The representation of BRICS in global economic governance: reform and fragmentation of multilateral institutions. In BRICS and the global economy, ed. K.S. Yeon, 1-34. Singapore: World Scientific Publishing. 
Oldekop, J. A. et al. 2020. COVID-19 and the case for global development. World Development 134(5):105044. https://doi.org/10.1016/j.worlddev.2020.105044.

Özçelik, S. 2005. Neorealist and Neo-Gramscian Hegemony in international relations and conflict resolution during the 1990's. Ekonomik ve Sosyal Arattrmalar Dergisi 1: 88-114.

Petrone, F. 2019. BRICS, soft power and climate change: new challenges in global governance? Ethics \& Global Politics 12 (2): 19-30.

Petrone, F. 2019. A specter is haunting the west (?): the BRICS and the future of global governance. The Rest: Journal of Politics and Development 9 (1): 20-32.

Petrone, F. 2020. Three ways to explore the BRICS (possible) impact on the future global order. The Rest: Journal of Politics and Development 10 (2): 6-20.

Petrone, F. (forthcoming/2021) The BRICS and the international institutions system: will they be able to reform United Nations and give a new impetus to global governance? International Studies, SAGE (in press).

Poskitt, A., A. Shankland, and K. Taela. (2016) Civil society from the BRICS: emerging roles in the new international development landscape. Brighton : Institute of Development Studies (IDS), 48 pp. [IDS Evidence Report 173].

Scholte, J.A., ed. 2011. Building global democracy? Civil Society and Accountable Global Governance. Cambridge: Cambridge University Press.

Stephen, G., and D. Law. 1993. Global hegemony and the structural power of capital. In Gramsci, historical materialism, and international relations, ed. Stephen Gill, 93-127. New York: Cambridge University Press.

Stiglitz, J.E. 2002. Globalization and its discontents. London: Penguin.

Stuenkel, O. 2016. Post-western world how emerging powers are remaking global order. Cambridge: Polity Press.

Stuenkel, O. 2020. The BRICS and the future of global order, 2nd ed. Lanham: Lexington Books.

Weiss, T.G. 2013. Global governance: Why? What? Whither? Cambridge: Polity Press.

Xinhua (2017) BRICS ready to play its role in global governance. China daily, August 07. http://www. chinadaily.com.cn/opinion/2017-08/07/content_30350595.htm. Accessed 23 February 2021.

Publisher's Note Springer Nature remains neutral with regard to jurisdictional claims in published maps and institutional affiliations. 